DOI 10.23859/2587-8344-2020-4-4-8

Борис Николаевич Ковалев

Санкт-Петербургский институт истории РАН,

Санкт-Петербург, Россия

https://orcid.org/0000-0002-1904-1844,

bnkov@mail.ru

Boris N. Kovalev

Saint-Petersburg Institute of History of the RAS,

Saint-Petersburg, Russia

https://orcid.org/0000-0002-1904-1844,

bnkov@mail.ru

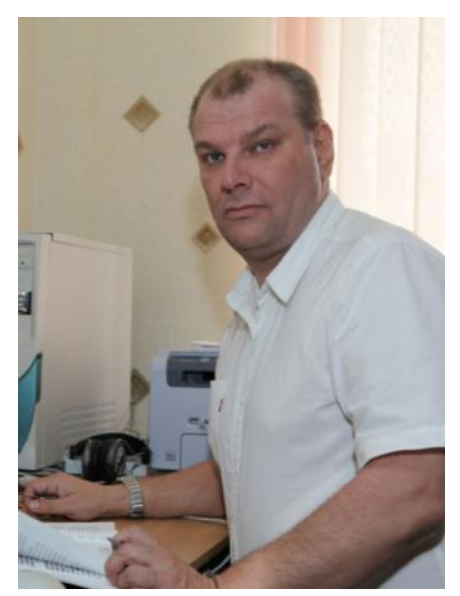

\author{
О причинах негативного отношения \\ советских органов безопасности к Армии Крайовой*
}

\section{On the Reasons for the Negative Attitude of the Soviet Security Agencies towards the Home Army}

Аннотацияя. В статье анализируется публикация польского историка Дариуша Рогута «Отношение советских органов безопасности к Армии Крайовой (июль 1944 - январь 1945 гг.)». Причины проблем во взаимоотношениях советских органов госбезопасности и подпольной польской военной организации «Армия Крайова» в завершающий период Второй мировой войны видятся в сложных взаимоотношениях между советским руководством в Москве и польским правительством в Лондоне.

Ключевые слова: Вторая мировая война, советско-польские отношения, Армия Крайова, советские органы государственной безопасности.

Abstract. The article analyzes the publication of the Polish historian Dariusz Rogut "The Attitude of Soviet Security Organs to the Home Army (July 1944 - January 1945).” The reasons for the problems in the relationship between the Soviet State Security Organs and the underground Polish military organization "Home Army" in the final period of the Second World War are seen in

* Для цитирования: Ковалев Б.Н. О причинах негативного отношения советских органов безопасности к Армии Крайовой // Historia Provinciae - Журнал региональной истории. - 2020. - T. 4. - № 4. - C. 1360-1376. DOI: 10.23859/2587-8344-2020-4-4-8

For citation: Kovalev, B. "On the Reasons for the Negative Attitude of the Soviet Security Agencies towards the Home Army." Historia Provinciae - The Journal of Regional History, vol. 4, no. 4 (2020): 1360-76, http://doi.org/10.23859/2587-8344-2020-4-4-8

(C) Ковалев Б.Н., 2020

(C) Kovalev B., 2020 
the complex relationship between the Soviet leadership in Moscow and the Polish government in London.

Key words: Second World War, Soviet-Polish relations, Home Army, Soviet State Security Organs

Если друг оказался вдруг

И не друг, и не враг - а так...

В. Высоиякий

Статью Дариуша Рогута «Отношение советских органов безопасности к Армии Крайовой (июль 1944 - январь 1945 гг.)» можно считать современным взглядом польской исторической науки на одну из проблем взаимоотношений между нашими государствами в XX веке.

Истина «враг моего врага - мой друг» в реалиях международных отношений далеко не всегда абсолютна. Тем более, когда речь идет о событиях Второй мировой войны.

Во времена моего советского детства всячески подчеркивалась роль польских солдат, которые плечом к плечу с Красной армией освобождали свою Родину и брали Берлин. Кстати, трагедия Варшавского восстания и Армии Крайовой тогда не замалчивалась. Вспомним хотя бы фильмы Анджея Вайды. Однако после 1989 г. в советско-польских, а с 1991 г. - российско-польских отношениях начинается не самая светлая полоса. Мы больше говорим о взаимных обидах, а не о том, что могло бы стать предметом совместного вдумчивого научного обсуждения.

Ответ на заявленную в статье Дариуша Рогута проблему «Отношение советских органов безопасности к Армии Крайовой (июль 1944 - январь 1945 гг.)» можно дать очень кратко: очень плохое, можно сказать, преступное. При этом автор постоянно апеллирует к нормам международного права.

Но для того, чтобы лучше понять заявленную проблему, я бы не стал ограничиваться указанными хронологическими рамками. Ведь все начиналось гораздо раньше. Практически с возрождения Польского государства в 1918 году. Весь межвоенный период Польша вполне заслуженно рассматривалась в качестве потенциального противника Советского Союза. Непримиримые позиции сторон, взаимное недоверие, открытая вражда нашли свое отражение в совместной активизации деятельности противоборствующих спецслужб двух стран ${ }^{1}$.

Следует вспомнить, что у Второй Речи Посполитой не складывались отношения с большинством соседей: Советским Союзом, Германией, Чехословаки-

${ }^{1}$ См. подробнее: Зданович А.А. Польский крест советской контрразведки. Польская линия в работе ВЧК-НКВД. 1918-1938 гг. - Москва: Крафт+, 2017. 
ей, Литвой. Но в среде польской элиты было весьма сильно́ агрессивнооптимистическое отношение к возможной будущей войне. Здесь любопытны воспоминания практически канонизированного в современной Польше Яна Карского (в 1998 году он был номинирован на Нобелевскую премию мира). О своей мобилизации в армию 24 августа 1939 года он позднее вспоминал так:

На вокзале было столько народу, будто там столпились все мужчины Варшавы. "Секретной” эту мобилизацию, подумал я, можно назвать только в том смысле, что нет никаких объявлений - ни на стенах, ни в газетах. Но призваны были сотни тысяч человек...Вид у всех был бравый и уверенный... Помню, на одном полустанке мальчишка лет двадцати кричал: "Хватит, мама, отпусти, скоро приедешь ко мне в Берлин!"”

Подобный оптимизм разделяли и многие кадровые офицеры:

Мы заключали, что наша мобилизация - тонкий ход в войне нервов с немцами. Германия слаба, Гитлер просто блефует. Когда он увидит, что Польша “сильна, едина и готова дать отпор", то отступит, и мы вернемся по домам. Если же нет, то Польша, с помощью Англии и Франции, как следует проучит этого сумасшедшего паяца.

А наш майор однажды вечером и вовсе заявил:

- На этот раз нам не надо никакой Англии и Франции. Мы и сами прекрасно справимся ${ }^{3}$.

Но Польша оказалась практически разбита за первые недели начавшейся войны.

Не буду вдаваться в обсуждение событий 1939 года и реального хода начавшейся Второй мировой войны, но хотелось бы напомнить о «Соглашении о восстановлении дипломатических отношений между СССР и правительством Польской Республики в изгнании». Этот документ более известен как «договор Майского - Сикорского». Подписанный в июле 1941 года в Лондоне, при безусловном нажиме на польскую сторону со стороны руководства Великобритании, он должен был ознаменовать процесс формирования союза стран антигитлеровской коалиции.

Относительная идиллия советско-польских отношений закончилась весной 1943 года. Здесь я не буду вдаваться в подробности Катынской трагедии. Разве что вспомню свою статью «Катынская трагедия и Холокост» ${ }^{4}$.

${ }^{2}$ Карский Ян. Я свидетельствую перед миром: история подпольного государства / перевод с французского языка Н. Малевич. - Москва: Астрель, 2012. - С. 40-41.

${ }^{3}$ Карский Ян. Я свидетельствую перед миром: история подпольного государства. - С. 42. 
Рассматривая трагедию польских граждан под Смоленском, мы не ставим под сомнение сам факт уничтожения этих людей сотрудниками НКВД перед началом Великой Отечественной войны. Однако при этом возникает вопрос: как могли гитлеровцы, так пристально изучавшие факты злодеяний «кровавого сталинского режима», почти два года не замечать очевидное. Ведь под Катынью расстрелы начались еще с начала 30-х годов. О них было хорошо известно местным жителям. Торжественные перезахоронения «жертв коммунизма» при содействии гитлеровцев были широко распространены в первые недели оккупации различных районов Советского Союза. Об этом писали коллаборационистские газеты, снимались сюжеты для документального кино.

Можно предположить, что гитлеровцы выявили факты расстрелов в Катыни гораздо раньше, чем они были официально обнародованы. Весной 1943 года, после Сталинградской битвы, стало понятно, что нацистская Германия и ее союзники имеют все меньше и меньше шансов на победу. В этих условиях среди стран-сателлитов III Рейха наметилось своего рода «брожение». Некоторые из политиков этих стран стали зондировать почву для возможных сепаратных переговоров со странами антигитлеровской коалиции. В стан врагов было необходимо внести раскол, недоверие друг к другу. Это отлично понимали в нацистской Германии.

Трагедия в Катынском лесу была широко использована нацистами для нескольких своих целей. Одной из них является обоснование Холокоста на оккупированной территории Европы. Что же касается отношений между Москвой и польском правительством в Лондоне, то им пришел конец. 25 апреля 1943 года СССР разорвал дипломатические отношения с ним. Его обвинили в сотрудничестве с немцами после того, как польское правительство согласилось на расследование Международного Красного Креста на оккупированной немцами территории в отношении захоронений в Катынском лесу. Прекрасно организованный план немецких пропагандистов достиг своего результата.

Польское правительство в Лондоне перешло для Москвы из категории союзников в категорию, скорее, противников. Кроме этого, трудно представить, что Иосиф Сталин за время обучения в Тифлисской духовной семинарии напитался там истинного христианского смирения. Я представляю его реакцию на карикатуры печатных изданий Армии Крайовой, где одинаково отвратительно изображались как Адольф Гитлер, так и он сам. А эта информация, естественно, до Кремля доходила в весьма полном объёме.

${ }^{4}$ Ковалев Б.Н. Катынская трагедия и антисемитская нацистская пропаганда // Холокост на территории CCCP = The Holocaust in the Soviet Union: материалы XIX Международной ежегодной конференции по иудаике / редколлегия: И. Альтман, А. Зельцер (ответственный редактор), А. Шнеер. - Москва: Сэфер, 2012. - С. 7-14. 
Я не собираюсь ставить под сомнение подвиг рядовых бойцов АК и их непосредственных командиров в борьбе с нацизмом. Кстати, как пишет Дариуш Рогут, многие из них потом получили возможность сражаться с врагом в рядах Войска Польского. Те, кто действительно воевали, а не дезертировали (это тоже из его статьи).

Советское политическое руководство и его боевой отряд - органы государственной безопасности - считали своими противниками структуры, выполнявшие распоряжения польского правительства в Лондоне. Но вопрос: а само польское лондонское правительство готово ли было считать тогда Сталина и Советский Союз своими союзниками?

Для примера можно рассмотреть события во Львове. Жизнь этого города в Речи Посполитой была идиллической только в песенке "Tylko we Lwowie" («Только во Львове»). При Пилсудском здесь велась политика пацификации, направленная на усмирение украинского населения. Другим видом деятельности была активная полонизация Галиции.

Солдат АК Юзеф Хальски так вспоминал события июля 1944 года: «Части Армии Крайовой совместно с советскими освободили Львов. На шпиле ратуши был поднят бело-красный флаг Польши, рядом с ним развевались американский и британский флаги» ${ }^{5}$.

У Дариуша Рогута: «В городе царила радостная атмосфера. По воспоминаниям секретаря Львовского городского комитета КП(б) Украины Чуписа: “В первый день после освобождения Львова Красной Армией от немецких фашистских захватчиков чувствовалось хорошее настроение среди польской части населения, чему способствовала работа польских националистов. Почти на всех домах были вывешены национальные флаги, поляки ходили вооруженные, с повязками на руках"».

Вопрос: Как на такой демарш должно было реагировать советское руководство? Тем более, что вопрос о будущих польских границах решался Сталиным вместе с союзниками. И он решался в пользу передачи Польше восточных территорий Германии.

Представляется спорным утверждение Дариуша Рогута о том, что «постепенно стали усиливаться репрессии НКВД и НКГБ в отношении польского населения. Русские обращались со всеми жителями Виленщины, включая поляков, как с гражданами своего собственного государства. Они считали, что эти люди обязаны проходить военную службу в рядах советской армии».

Призыв в ряды армии, сражающейся с гитлеровцами, сложно назвать «репрессией».

${ }^{5}$ Шарек Я. Из хроники коммунизма: Бунт каторжника К-677 / литературная запись бесед с Ю. Хальски; перевод с польского В. Биргер // Норильская голгофа / составитель О.Л. Подборская. - Красноярск: [б.и.], 2002. - С. 139. 
Можно полностью согласиться с утверждением Дариуша Рогута о том, что «Советская сторона не могла допустить существования независимых вооруженных частей в тылу РККА, тем более, что их считали враждебными и опасными». В значительной мере репрессии по отношению к АК и были вызваны этим.

Рассматривая события тех лет, можно обращаться к польским или советским источникам. Но следует посмотреть и на те, что не имеют отношения ни к Польше, ни к Советскому Союзу. Весьма любопытным источником по истории советско-британских отношений в годы Второй мировой войны является газета «Британский союзник». Она издавалась с августа 1942 года министерством информации Великобритании по договорённости с советскими властями на русском языке. Там немало достаточно раздраженных материалов, обвиняющих Польшу в неблагодарности и безответственности.

Польское правительство в изгнании считало себя равноправным партнером. Но насколько это (особенно в вопросе послевоенного устройства мира) принималось ее западными союзниками? Может быть, именно поэтому мы читаем в статье Дариуша Рогута следующее: «Перед массовыми арестами солдат АК и польских граждан правительство Польской республики в изгнании предприняло решительные дипломатические действия в отношении западных держав... К сожалению, дипломатическая деятельность, протесты и призывы правительства и польского общества не принесли никаких результатов. Союзники же не предприняли никаких действий в защиту польского подполья и территориальной целостности своего самого верного соратника».

Можно задать вопрос: а почему это произошло? Ответ напрашивается следующий: в реалиях еще не закончившихся боевых действий военноэкономический потенциал Советского Союза для США и Великобритании представлялся гораздо более важным аргументом, чем политические амбиции правительства в изгнании.

Самым массовым видом советских репрессий на территориях проживания польского населения после их освобождения от немецкой оккупации стало интернирование. Интернированию подверглось большинство поляков и польских граждан, задержанных в 1944-1945 гг. органами контрразведки «СМЕРШ» Наркомата обороны и внутренними войсками НКВД

В 1944 г. поводом для арестов служили обвинения в диверсионной, террористической и шпионской деятельности, направленной против Красной Армии, в уклонении от призыва в польскую армию или же в сотрудничестве с герман-

${ }^{6}$ Кузнеиов И.Н. Интернирование поляков с территории западных областей СССР (19441947 гг.) // Беларуска-польскія адносіны: гісторыя і сучаснасць: матэрыялы Міжнароднага круглага стала (Мінск, 30 кастрычніка 2014 г.) / рэдкалегія: В.Г. Шадурскі (адк. рэд.) [i інш.]. - Мінск: Выдавецкі цэнтр БГУ, 2015. - С. 36. 
скими оккупационными органами. Фактически основной целью повальных арестов было уничтожение мощного польского некоммунистического антигитлеровского подполья и его вооруженных сил - Армии Крайовой.

В начале 1945 г., кроме участников Армии Крайовой, интернированию подверглись поляки из довоенных западных воеводств Польши, задержанные как члены различных немецких организаций (молодежных, профсоюзных, женских), как служащие органов местной администрации или как принявшие германское подданство ${ }^{7}$.

После отправки вглубь СССР интернированные поляки и польские граждане - солдаты Армии Крайовой и других подпольных структур - направлялись в лагеря для военнопленных германской и союзных ей армий, подчинявшиеся ГУПВИ НКВД-МВД.

Интернированные польские граждане содержались во многих лагерях на территории всего бывшего СССР, причем большинство из них хотя бы один раз переводились из лагеря в лагерь.

Согласно докладной записке Л.П. Берии на имя И.В. Сталина от 17 июня 1945 г., в лагерях и тюрьмах НКВД СССР находилось 8311 «лиц командного и рядового состава “Армии Крайовой”». В документе подчеркивалось, что «участие этих людей в “АК” подтверждается материалами, изъятыми на территории Польши в 1944 году». Членов АК Лаврентий Берия характеризовал как «активных участников террористических и диверсионных групп, содержателей конспиративно-явочных квартир и агентов гестапо, изъятых на территории Польши в 1944 году» ${ }^{8}$.

Для интернированных солдат АК одним из видов тяжелейшего морального унижения был факт, что их стали размещать вместе с военнопленными немцами. При этом часто у бывших солдат вермахта условия содержания были лучше. Поляки вспоминали: «То, что нас поселили в одном лагере с ними, превзошло все наши ожидания. Из эшелона в лагерь Шиботово пригнали около 1000 человек. В лагере для поляков были подготовлены два свободных барака. Каждый из них мог вместить до 300 человек, а нас прибыло почти в два раза больше» ${ }^{9}$.

В СССР в послевоенные годы труд военнопленных и интернированных использовался повсеместно. Часть контингента использовалась на лесозаготовках.

${ }^{7}$ Кузнецов И.Н. Интернирование поляков с территории западных областей СССР (19441947 гг.). - С. 37.

${ }^{8}$ См.: НКВД и польское подполье. 1944-1945 гг. (по «Особым папкам» И.В. Сталина): сборник документов / ответственный редактор А.Ф. Носкова. - Москва: Институт славяноведения и балканистики РАН, 1994 - Москва: ИСБ, 1994. - С. 199.

${ }^{9}$ Цит. по: Александрова Г.А. Военнопленные и интернированные Второй мировой войны на территории Боровичского края (1942-1952 гг.) // Ежегодник Новгородского государственного объединенного музея-заповедника за 2002 г. - Великий Новгород: НГОМЗ, 2003. C. 109 . 
Помимо внешних работ интернированные поляки трудились в лагерных мастерских по изготовлению предметов ширпотреба. Они выводились на эти работы ежедневно, кроме воскресений.

Дариуш Рогут делает вывод, что на смену нацистской оккупации для «многих поляков» пришла оккупация советская: «Аресты, интернирование, осуждение (по советскому законодательству), а также массовые депортации нарушали международное право. Для многих поляков начался очередной период оккупации, на этот раз - советской».

Однако если обратиться к нормам международного права, возникает вопрос: как тогда в условиях «советской оккупации» Польская народная республика была официально признана практически всеми государствами мира, в том числе Великобританией, Францией и США? Кстати, последние имели консульства почти во всех крупных польских городах.

К сожалению, в статье польского исследователя нет ничего о жертвах, которые понесла Красная армия при освобождении Польши. Для меня эти жертвы не пустой звук. С раннего детства помню сложенную как будто из кубиков раненую ногу моего родного деда. Пройдя всю войну с 1941 года без царапины, в том числе и Сталинград, он был тяжело ранен в январе 1945 на Висле.

Мне лично искренне жаль рядовых бойцов Армии Крайовой, ставших жертвами большой политической игры. Они действительно не понимали, за что их репрессировали. Так, польский интернированный Роман Владислав Бар вспоминал, что, когда его вместе с товарищами вели колонной из Боровичей, под охраной, дети кидали в них камнями и кричали: «Фашисты!»

Однако по словам этого бывшего солдата Армии Крайовой, ситуация значительно поменялась после 9 мая 1945 года. Тогда русское население стало относиться к ним с большим пониманием и сочувствием ${ }^{10}$. Тем более следует отметить, что непонимание разницы между военнопленным и интернированным было характерно для абсолютного большинства местного населения. Да и долгие годы войны ожесточили многих людей. Кто-то из них потерял на фронте родных и близких.

В истории польско-российских отношений не так много светлых страниц. За века накопилось немало совместных обид. Но здесь хочется вспомнить ссыльных поляков XIX века. Монах Ченстоховского монастыря Бонавентура Гавельчик после восстания 1863 года 17 лет провел в Новгородской губернии. Из ссылки он писал своему брату: «Не грустите, не скучайте и не плачьте, не думайте, что люди русские съедят поляка, как только он у них появится. С поляками обходятся так же, как мы в Царстве Польском с россиянами, и даже здесь более и более вижу откровенности, любезности, помощи и доброго сердца, чем имеют некоторые из поляков. Верьте мне, когда говорю это вам от сердца» ${ }^{11}$.

${ }^{10}$ Из беседы автора с Романом Баром. 10 октября 2014 года.

11 Письмо Б. Гавельчика брату // Государственный архив Новгородской области. Ф. 117. - Оп. 1. - Д. 113. - Л. 9 (Перлюстрация жандармами переписки польских ссыльных). 
Вторая мировая война принесла страдания миллионам людей. Воспоминания об этом являются памятью и предостережением для нас, живущих в XXI веке.

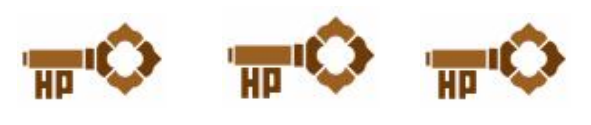

If your friend has suddenly turned out To be neither friend nor foe... - Vladimir Vysotsky

The article of Dariusz Rogut "The Attitude of Soviet Security Organs to the Home Army (July 1944 - January 1945)" can be regarded as a modern view of Polish historical science on one of the problems in relations between our states in the $20^{\text {th }}$ century.

In the realities of international relations, the maxim that the enemy of my enemy is my friend is far from always being unconditional, especially when it comes to the events of the Second World War.

During my Soviet childhood, the role of the Polish soldiers was emphasized in every possible way. Shoulder to shoulder with the Red Army, they liberated their homeland and captured Berlin. By the way, the tragedy of the Warsaw Uprising and the Home Army (Armia Krajowa, hereinafter AK) was not hushed up then. Let us recall at least the films of Andrzej Wajda. However, after 1989, Soviet-Polish and, since 1991, Russian-Polish relations hit a rough patch. We are talking more about mutual accusations but not about what could have become the subject of joint thoughtful scientific discussion.

The answer to the problem stated in the Dariusz Rogut's article "The Attitude of the Soviet Security Organs to the Home Army (July 1944 - January 1945)" can be very brief: it was very bad, one might say, even criminal attitude. At the same time, the author constantly appeals to the norms of international law.

However, in order to better understand the stated problem, I would not limit myself to the indicated chronological framework. After all, it all started much earlier, practically, with the revival of the Polish state in 1918. Throughout the entire interwar period, Poland was reasonably regarded as a potential enemy of the Soviet Union. The uncompromising positions of the parties, mutual distrust, and open 
enmity were reflected in the mutual intensification of activities of the antagonistic special services of the two countries. ${ }^{1}$

It should be remembered that the Second Polish Republic had quite tense relations with most of its neighbours: The Soviet Union, Germany, Czechoslovakia, and Lithuania. But among the Polish elite there was a very aggressive and optimistic attitude towards a possible future war. In this regard, of particular interest are the memoirs of Jan Karski, who is practically canonized in modern Poland (in 1998, he was nominated for the Nobel Peace Prize). He later recalled his mobilization into the army on August 24, 1939:

When I got to the railway depot it looked as though every man in Warsaw were there. I quickly realized that the mobilization was "secret" only in the sense that there were no public announcements or posters. Hundreds of thousands of men must have been called.... Everyone looked full of energy, enthusiastic, and even exhilarated.... "Let me go, Mother," I remember hearing a boy of about twenty call out loudly at one of the stations. "Soon you can come and visit me in Berlin."2

This optimism was shared by many career officers:

... the conclusion that our mobilization was simply the Polish riposte to the Nazi war of nerves. Germany was weak and Hitler was bluffing. When he saw that Poland was strong, united, and prepared, he would back down quickly and we should all go home. If not, the farcical little fanatic would be taught a severe lesson by Poland and, if necessary, by England and France.

One evening our Major said:

"England and France are not needed this time. We can finish this alone."

But Poland was practically defeated right in the first weeks of the outbreak of the war.

I will not go into a debate on the events of 1939 and the real course of the outbreak of the Second World War, but I would like to recall the Agreement on the Restoration of Diplomatic Relations between the USSR and the Government of the Republic of Poland in exile, better known as the Sikorski-Mayski Agreement. Signed in July 1941 in London, with the British leadership exerting pressure on the Polish side, it was supposed to mark the process of forming an alliance of the anti-Hitler coalition countries.

${ }^{1}$ For more, see A.A. Zdanovich, The Polish Cross of Soviet Counterintelligence. The Polish Direction in the Work of the VCheKa-NKVD. 1918-1938 [in Russian] (Moscow: Kraft +, 2017).

${ }^{2}$ Yan Karskii, My Report to the World: Story of a Secret State [in Russian], transl. N. Malevich (Moscow: Astrel', 2012), 40-41.

${ }^{3}$ Karskii, My Report to the World, 42. 
This comparative idyll in Soviet-Polish relations ended in the spring of 1943. I will not go into detail on the issue of the Katyn tragedy, except that I can mention my article "The Katyn Tragedy and the Holocaust.",

Considering the tragedy of Polish citizens near Smolensk, we do not question the very fact of the slaughter of these people by the NKVD before the start of the Great Patriotic War. However, this raises the question: How could the Nazis, who so closely studied the facts of the atrocities of the bloody Stalin's regime for almost two years, not notice the obvious? After all, executions near Katyn began in the early 1930s. The locals were well aware of them. Solemn reburials of the victims of communism with the assistance of the Nazis were widespread in the first weeks of the occupation of various regions of the Soviet Union. Collaboration newspapers wrote about this and documentary films were shot.

It can be assumed that the Nazis had revealed the facts of the executions in Katyn much earlier than they were officially made public. In the spring of 1943, after the Battle of Stalingrad, it became clear that Nazi Germany and its allies were less and less likely to win. Under these conditions, a kind of ferment started among the satellite countries of the Third Reich. Some of the politicians of these countries began to examine the situation for possible separate negotiations with the countries of the anti-Hitler coalition. It was necessary to create divisions and mutual distrust in the enemy camp. This was well understood in Nazi Germany.

The tragedy in the Katyn Forest was widely used by the Nazis for several of their purposes. One of these purposes is the justification of the Holocaust in the occupied territory of Europe. As for the relationship between Moscow and the Polish government in London, they were terminated. On April 25, 1943, the USSR broke off any diplomatic relations with it. The Polish government was accused of collaborating with the Germans after it had agreed to an investigation of burials in the Katyn Forest by the International Red Cross in German-occupied territory. The perfectly organized plan of the German propagandists achieved its results.

For Moscow, the Polish government in London moved from the category of allies to the category of opponents. In addition, it is difficult to imagine that during his studies at Tiflis Theological Seminary, Joseph Stalin was imbued with true Christian humility. I can imagine his response to the caricatures published in the Home Army printed media, which portrayed both Adolf Hitler and himself in the same disgusting manner. And this information, of course, reached the Kremlin in its entirety.

I'm not going to question the valour of the ordinary AK soldiers and their immediate commanders in the fight against Nazism. By the way, as Dariusz Rogut notes, many of them later had the opportunity to fight the enemy in the ranks of the

${ }^{4}$ B.N. Kovalev, "Katyn Tragedy and Anti-Semitic Nazi Propaganda" [in Russian], in The Holocaust in the Soviet Union: Proceedings of the $19^{\text {th }}$ Annual International Conference on Jewish Studies, ed. I. Altman, A. Zeltser, A. Shneyer (Moscow: Sefer, 2012), 7-14. 
Polish Army. It concerns, however, only those who really fought but did not simply defect (this is also from his article).

The Soviet political leadership and its combat unit, the state security organs, regarded the structures that carried out the orders of the Polish government in London as their opponents. But the question is wither the Polish government in London was ready to regard Stalin and the Soviet Union as its allies.

For example, let us consider the events in Lvov. The life of this city of Rzeczpospolita was idyllic only in the song "Tylko we Lwowie" ("Only in Lvov"). Under Piłsudski, a policy of pacification was pursued there, aimed at pacifying the Ukrainian population. Active polonization of Galicia was another kind of activity there.

Józef Halski, an AK soldier, recalled the events of July 1944 as follows: "The Home Army, together with the Soviets, liberated Lvov. The white and red flag of Poland was hoisted on the spire of the town hall, and the American and British flags were waving next to it."

Dariusz Rogut writes: "A joyful atmosphere reigned in the city. According to the memoirs of the secretary of the Lvov city committee of the Communist Party of Ukraine Chupis, 'on the first day after the liberation of Lvov from the German fascist invaders by the Red Army, a good mood was felt among the Polish part of the population, which was facilitated by the work of Polish nationalists. National flags were hung almost on all buildings, and Poles carried arms and wore armbands."”

Question: How should the Soviet leadership react to such a demarche? What is more, the issue of the future Polish borders was being resolved by Stalin together with the allies. And it was resolved in favour of transferring the eastern territories of Germany to Poland.

Dariusz Rogut makes a rather controversial statement that "repression of the NKVD and NKGB against the Polish population of Vilnius region became stronger. The Russians treated all the residents of the Vilnius region, including Poles, as citizens of their own state. They believed that those people were obliged to do military service in the Soviet army."

The recruitment into the ranks of the Soviet army fighting the Nazis can hardly be called repression.

We can fully agree with Dariusz Rogut's statement that "the Soviet party could not allow the existence of independent armed units in the rear of the Red Army, especially since they were considered hostile and dangerous." To a large extent, repression against the $\mathrm{AK}$ was caused by this fact.

5 Ya. Sharek, "From the Chronicle of Communism: Riot of convict K-677" [in Russian], literary record of conversations with Józef Halski, trans. V. Birger, in Norilsk Golgotha, comp. O.L. Podborskaya (Krasnoyarsk: [n.p.], 2002), 139. 
Considering the events of those years, one can refer to Polish or to Soviet sources. But one should also look at the sources that have nothing to do with either Poland or the Soviet Union. A very interesting source on the history of Soviet-British relations during the Second World War is the newspaper Britanskii soyuznik [British Ally]. It was published in the Russian language by the British Ministry of Information under the agreement with the Soviet authorities starting from August 1942. The newspaper contains quite a few angry pieces accusing Poland of ingratitude and irresponsibility.

The Polish government-in-exile considered itself an equal partner. But to what extent was this accepted by its Western allies (especially considering the subject of the post-war world order)? Perhaps that is why in Dariusz Rogut's article we find the following: "Before the beginning of the mass arrests of AK soldiers and Polish citizens, the Government of the Republic of Poland in exile took decisive diplomatic action in relation to the Western powers.... Unfortunately, diplomatic activities, protests and appeals by the government and Polish society did not yield any results. The Allies did not take any action in defence of the Polish underground and the territorial integrity of their most loyal ally."

One can ask the question why this happened. The following answer seems most probable: in the realities of the still on-going hostilities, the military and economic potential of the Soviet Union appeared to the United States and Great Britain as a much more important argument than the political ambitions of the government in exile.

Internment became the most widely spread way of repression used by the Soviets in the territories inhabited by the Polish population after their liberation from German occupation. Most Poles and Polish citizens who were detained in 1944-45 by the Soviet counterintelligence agency SMERSH of the People's Commissariat of Defence and by the internal troops of the NKVD underwent internment. ${ }^{6}$

In 1944, the grounds for arrest included charges of sabotage, terrorist and espionage activities directed against the Red Army, charges of evading recruitment into the Polish army, or of cooperation with the German occupation authorities. In fact, the main goal of mass arrests was to destroy the powerful Polish non-communist anti-Hitler underground and its armed forces, the Home Army.

At the beginning of 1945, in addition to the AK members, internment was applied to Poles from the pre-war western provinces of Poland who were detained as members of various German organizations (youth and women's organisations, trade

${ }^{6}$ I.N. Kuznetsov, "The Internment of Poles from the Territory of the Western Regions of the USSR (1944-1947)" [in Russian], in Belarusian-Polish relations: History and Modernity: Proceedings of the International Round Table, Minsk, October 30, 2014, ed V.G. Shadurski et al. (Minsk: Vydavetski tsentr BGU, 2015), 36. 
unions), as employees of local administration or as those who had taken German citizenship. ${ }^{7}$

After being sent deep into the USSR territories, interned Poles and Polish citizens, including soldiers of the Home Army and other underground structures, were sent to the POW camps of the German and allied armies, subordinated to the Main Administration for Affairs of Prisoners of War and Internees (GUPVI NKVDMVD).

The interned Polish citizens were held in many POW camps throughout the entire former USSR, and most of them were transferred from one camp to another at least once during their imprisonment.

According to the memorandum of Lavrenty Beria to Joseph Stalin as of June 17, 1945, in the camps and prisons of the NKVD of the USSR there were 8,311 "soldiers and officers of the Home Army." The document emphasized that "the fact that these people belong to the Home Army is confirmed by the materials confiscated in the territory of Poland in 1944." Lavrenty Beria characterized the AK members as "active members of terrorist and sabotage groups, owners of secret safe houses and Gestapo agents seized in Poland in 1944.",

As for the interned AK soldiers, one of the forms of severe moral humiliation was the fact that they were accommodated together with German prisoners of war and the conditions of detention of the former Wehrmacht soldiers were even better. "The fact that we were settled in the same camp with them surpassed all our expectations. About 1,000 people were brought from the train to the Shibotovo camp. In the camp, two uninhibited barracks were prepared for the Poles. Each of these barracks could accommodate up to 300 people, and there were almost twice as many of us," the Poles recalled. $^{9}$

In the post-war years, the labour of prisoners of war and internees was used everywhere in the USSR. Part of the contingent was used for timber harvesting. In addition to outdoor work, interned Poles worked in camp workshops manufacturing consumer goods. They were sent to work every day except Sundays.

Dariusz Rogut concludes that for many Poles, the Nazi occupation was replaced by the Soviet occupation. "Arrests, internment, conviction (under Soviet law), and mass deportations violated international law. For many Poles, another period of occupation began, and this time it was the Soviet occupation," he writes.

\footnotetext{
${ }^{7}$ Kuznetsov, "The Internment of Poles," 37.

8 A.F. Noskova, ed., The NKVD and the Polish Underground. 1944-1945 (according to 'Special folders' of Joseph Stalin): A Collection of Documents [in Russian] (Moscow: Institut slavyanovedeniya i balkanistiki RAN, 1994), 199.

${ }^{9}$ Cited in G.A. Aleksandrova, "Prisoners of war and internees of the Second World War in the territory of the Borovichi region (1942-1952)" [in Russian], in 2002 Yearbook of the Novgorod State Museum-Reserve (Veliky Novgorod: NGOMZ, 2003), 109.
} 
However, if we turn our attention to the norms of international law, the question arises: How could it be possible that under the conditions of the "Soviet occupation" the Polish People's Republic was officially recognized by almost all states of the world, including Great Britain, France and the United States? By the way, the United Stated had their consulates in almost all major Polish cities.

Unfortunately, in the article by the Polish researcher there is nothing about the casualties the Red Army sustained during the liberation of Poland. For me, these casualties were not just empty words. Since my early childhood, I have remembered my grandfather's wounded leg, as if assembled from blocks. Having survived the entire war since 1941, including Stalingrad, without even a scratch, he was badly wounded in January 1945 on the Vistula.

I personally feel sorry for the ordinary rank and file soldiers of the Home Army who became victims of this great political game. They really did not understand why they were being repressed. For instance, the Polish internee Roman Wladyslaw Bar recalled that when he and his comrades were led under guard in a column from Borovichi, children threw stones at them, crying out loud, "Fascists!"

However, according to this former soldier of the Home Army, the situation changed significantly after May 9, 1945. Then, the Russian population began to treat them with greater understanding and compassion. ${ }^{10}$ Moreover, it should be noted that misunderstanding the difference between a prisoner of war and an internee was common among the majority of the local population. And the long years of war embittered many people. Some of them lost relatives and friends at the front.

There are not many bright pages in the history of Polish-Russian relations. Over the centuries, lots of mutual accusations have accumulated. But here I would like to recall the Polish exiles of the $19^{\text {th }}$ century. The monk of Częstochowa monastery Bonaventura Havelczyk spent 17 years in Novgorod Governorate after the January Insurrection of 1863. From exile, he wrote to his brother: "Do not be sad, do not be bored and do not cry, do not think that Russian people will eat a Pole as soon as he arrives in their lands. Poles are treated here in the same way as we treat Russians in the Kingdom of Poland, and here I even see more and more frankness, courtesy, help and kind hearts than some of the Poles have. Believe me when I tell you this from my heart." 11

The Second World War brought suffering to millions of people. Remembering it is memory and a warning for us living in the $21^{\text {st }}$ century.

${ }^{10}$ From the author's conversation with Roman Bar, October 10, 2014.

${ }^{11}$ Pis'mo B. Gavel'chika bratu [A letter from B. Havelczyk to his brother]. Perlyustratsiya zhandarmami perepiski pol'skikh ssyl'nykh [Perlustration of the correspondence of the Polish exiles by the gendarmes]. F. 117, op. 1, d. 113, 1. 9. Gosudarstvennyi arkhiv Novgorodskoi oblasti [State Archives of Novgorod Region], Veliky Novgorod, Russia. 


\section{Список литературы}

Александрова Г.А. Военнопленные и интернированные Второй мировой войны на территории Боровичского края (1942-1952 гг.) // Ежегодник Новгородского государственного объединенного музея-заповедника за 2002 г. - Великий Новгород: НГОМЗ, 2003. - С. 107113.

Зданович А.А. Польский крест советской контрразведки. Польская линия в работе ВЧКНКВД. 1918-1938 гг. - Москва: Крафт+, 2017. - 480 с.

Карский Ян. Я свидетельствую перед миром: история подпольного государства / перевод с французского языка Н. Малевич. - Москва: Астрель, 2012. - 445 с.

Ковалев Б.Н. Катынская трагедия и антисемитская нацистская пропаганда // Холокост на территории CCCP = The Holocaust in the Soviet Union: материалы XIX Международной ежегодной конференции по иудаике / редколлегия: И. Альтман, А. Зельцер (ответственный редактор), А. Шнеер. - Москва: Сэфер, 2012. - С. 7-14.

Кузнецов И.Н. Интернирование поляков с территории западных областей СССР (19441947 гг.) // Беларуска-польскія адносіны: гісторыя і сучаснасць: матэрыялы Міжнароднага круглага стала (Мінск, 30 кастрычніка 2014 г.) / рэдкалегія: В. Г. Шадурскі (адк. рэд.) [i інш.]. - Мінск: Выдавецкі цэнтр БГУ, 2015. - Мінск: Выдавецкі цэнтр БДУ, 2015. - С. 3643.

НКВД и польское подполье. 1944-1945 гг. (по «Особым папкам» И.В. Сталина): сборник документов / ответственный редактор А.Ф. Носкова. - Москва: Институт славяноведения и балканистики РАН, 1994. - 308 с.

Шарек Я. Из хроники коммунизма: Бунт каторжника К-677 / литературная запись бесед с Ю. Хальски; перевод с польского языка В. Биргер // Норильская голгофа / составитель О.Л. Подборская. - Красноярск: [б.и.], 2002. - С. 138-149.

\section{References}

Aleksandrova, G.A. "Voennoplennye i internirovannye Vtoroi mirovoi voiny na territorii Borovichskogo kraya (1942-1952 gg.)" [Prisoners of war and internees of the Second World War ion the territory of the Borovichi region (1942-1952)]. In Ezhegodnik Novgorodskogo gosudarstvennogo ob"edinennogo muzeya-zapovednika za 2002 g. - Veliky Novgorod: NGOMZ, 2003. (In Russian)

Zdanovich, A.A. Pol'skii krest sovetskoi kontrrazvedki. Pol'skaya liniya v rabote VChKNKVD. 1918-1938 gg. [The Polish cross of Soviet counterintelligence. The Polish direction in the work of the VCheKa-NKVD. 1918-1938]. Moscow: Kraft+, 2017. (In Russian)

Karskii, Yan. Ya svidetel'stvuyu pered mirom: istoriya podpol'nogo gosudarstva [My report to the world: story of a secret state]. Translated from French by N. Malevich. Moscow: Astrel', 2012. (In Russian)

Kovalev, B.N. "Katynskaya tragediya i antisemitskaya natsistskaya propaganda" [Katyn tragedy and anti-Semitic Nazi propaganda]. In Kholokost na territorii SSSR = The Holocaust in the Soviet Union: materialy XIX Mezhdunarodnoi ezhegodnoi konferentsii po iudaike [The Holocaust in the Soviet Union: Proceedings of the $19^{\text {th }}$ Annual International Conference on Jewish Studies], edited by I. Altman, A. Zeltser, A. Shneyer, 7-14. Moscow: Sefer, 2012. (In Russian)

Kuznetsov, I.N. "Internirovanie polyakov s territorii zapadnykh oblastei SSSR (19441947 gg.)" [The internment of Poles from the territory of the western regions of the USSR (19441947)]. In Belaruska-pol'skiya adnosiny: gistoryya i suchasnasts': materyyaly Mizhnarodnaga 
kruglaga stala, Minsk, 30 kastrychnika 2014 g. [Belarusian-Polish relations: history and modernity: Proceedings of the International Round Table, Minsk, October 30, 2014], edited by V.G. Shadurski, et al., 36-43. Minsk: Vydavetski tsentr BGU, 2015. (In Russian)

A.F. Noskova, ed., NKVD i pol'skoe podpol'e, 1944-1945 (Po 'Osobym papkam' I.V. Stalina): sbornik dokumentov [NKVD and the Polish underground, 1944-1945 (according to 'Special Folders' of J. Stalin): a collection of documents]. Moscow: Institut slavyanovedeniya i balkanistiki RAN, 1994. (In Russian)

Sharek, Ya. "Iz khroniki kommunizma: Bunt katorzhnika K-677" [From the chronicle of communism: Riot of convict K-677], literary record of conversations with Józef Halski, translated from Polish by V. Birger. In Noril'skaya golgofa [Norilsk Golgotha], compiled by O.L. Podborskaya, 138-49. Krasnoyarsk: [n.p.], 2002. (In Russian)

Ковалев Борис Николаевич

Доктор исторических наук, профессор,

Ведущий научный сотрудник

Санкт-Петербургского института истории

PAH,

Санкт-Петербург, Россия https://orcid.org/0000-0002-1904-1844,

bnkov@mail.ru
Boris N. Kovalev

Doctor of Historical Sciences, Professor

Leading researcher of the

Saint-Petersburg Institute of History of the

RAS,

Saint-Petersburg, Russia

https://orcid.org/0000-0002-1904-1844,

bnkov@mail.ru 